\title{
Pengaruh Moralitas Individu, Asimetri Informasi, dan Keefektifan Pengendalian Internal Terhadap Kecenderungan Kecurangan (Fraud) Berdasarkan Persepsi Pada Badan Pengelola Keuangan dan Barang Milik Daerah Provinsi Sulawesi Utara
}

\author{
SINTIA N. KOROMPIS ${ }^{1}$, DAVID P. E. SAERANG ${ }^{2}$, JENNY MORASA $^{3}$ \\ ${ }^{1,2,3}$ Program Magister Akuntansi, Fakultas Ekonomi dan Bisnis Universitas Sam Ratulangi \\ Email: sintiakorompis@gmail.com ${ }^{1}$,dpesaerang@gmail.com² ${ }^{2}$ jennymorasa@ hotmail.com ${ }^{3}$
}

\begin{abstract}
Fraud propensity is not only uncommon in private sector, but also in governmental sector. The fraud is in form of power abuses and errors in financial statement presented by public accountant. This paper intends to examine if individual morality, information asymmetry, and internal control effectivity have significant impacts on fraud propensity. This study utilised the perception of Financial Management Board and District Property North Sulawesi Province. Independent variables $(X)$ were individual morality $\left(X_{1}\right)$, information asymmetry $\left(X_{2}\right)$, and internal control effectivity $\left(X_{3}\right)$, whereas fraud propensity $(Y)$ was dependent variable. Multiple linear regression analysis was processed by SPSS Ver 22.0 in order to analyze data and evaluate hypothesis. This study demonstrates that (1) variable individual morality $\left(X_{1}\right)$ has a negative and significant impact on fraud propensity $(Y)$ which shows an increase of individual morality is paralleled by a decrease of fraud; (2)variable information asymmetry $\left(\mathrm{X}_{2}\right)$ has a positive and significant impact on fraud propensity $(Y)$ which corroborates that an increase of information asymmetry equals an increase of fraud; and (3) variable internal control effectivity $\left(X_{3}\right)$ has a negative and significant impact on fraud propensity which proves an increase of internal control effectivity is equivalent to a decrease of fraud.
\end{abstract}

Keywords: Individual Morality, Information Asymmetry, Internal Control Effectivity

\begin{abstract}
Abstrak. Kecenderungan kecurangan (fraud) tidak hanya terjadi di sektor swasta tapi bisa juga terjadi di sektor pemerintahan dalam bentuk penyalahgunaan wewenang dan kesalahan dalam penyajian laporan keuangan yang dilakukan oleh pengelola akuntansi pada sektor publik. Penelitian ini bertujuan mengetahui pengaruh moralitas individu, asimetri informasi, dan keefektifan pengendalian internal terhadap kecenderungan kecurangan (fraud). Penelitian ini dilakukan berdasarkan persepsi pada Badan Pengelola Keuangan dan Barang Milik Daerah Provinsi Sulawesi Utara. Pada penelitian ini variabel independen $(\mathrm{X})$ adalah moralitas individu $\left(\mathrm{X}_{1}\right)$, asimetri informasi $\left(\mathrm{X}_{2}\right)$, dan keefektifan pengendalian internal $\left(\mathrm{X}_{3}\right)$, sedangkan variabel dependen $(\mathrm{Y})$ adalah kecenderungan kecurangan (Y). Analisis data untuk menguji hipotesis dilakukan dengan menggunakan analisis linier berganda yang diolah program SPSS Ver 22.0. Hasil penelitian menunjukkan: (1) variabel moralitas individu $\left(\mathrm{X}_{1}\right)$ memiliki pengaruh signifikan negatif terhadap kecenderungan kecurangan $(\mathrm{Y})$ artinya semakin tinggi tingkat moralitas individu maka kecenderungan untuk melakukan kecurangan akan semakin rendah; (2) variabel asimetri informasi $\left(\mathrm{X}_{2}\right)$ memiliki pengaruh signifikan positif terhadap kecenderungan kecurangan $(\mathrm{Y})$ artinya jika asimetri informasi meningkat maka kecenderungan kecurangan juga meningkat; dan (3) variabel keefektifan pengendalian internal $\left(\mathrm{X}_{3}\right)$ memiliki pengaruh signifikan negatif terhadap kecenderungan kecurangan (Y) artinya semakin baik keefektifan pengendalian internal suatu instansi maka kecenderungan untuk melakukan kecurangan akan semakin menurun.
\end{abstract}

Kata Kunci: Moralitas Individu, Asimetri Informasi, Keefektifan Pengendalian Internal, Kecenderungan Kecurangan.

\section{Pendahuluan}

Dewasa ini, pemberitaan media yang kian terbuka membuat masyarakat dapat dengan mudah mengakses segala macam informasi yang dibutuhkan. Salah satunya mengenai informasi atas perkembangan dunia akuntansi. Banyak sekali pemberitaan yang muncul mengenai adanya kecurangan (fraud) yang terjadi di Indonesia diantaranya mengenai kasus manipulasi pajak, kasus perbankan, maupun kasus korupsi yang muncul dengan beragam cara.

Kecurangan adalah segala upaya yang dilakukan secara sengaja untuk menguntungkan diri sendiri dan merugikan orang lain. Hal ini senada dengan isi dari buku Black's Law Dictionary yang dikutip oleh Tunggal (2001) dijelaskan satu definisi hukum dari kecurangan, yaitu berbagai macam alat yang dengan lihai dipakai dan dipergunakan oleh seseorang untuk mendapatkan keuntungan terhadap orang lain, dengan cara bujukan palsu atau dengan menutupi kebenaran, dan meliputi semua 
cara-cara mendadak, tipu daya (trick), kelicikan (cunning), mengelabui (dissembling), dan setiap cara tidak jujur, sehingga pihak orang lain bisa ditipu, dicurangi atau ditipu (cheated). Berdasarkan penelitian Cressey (2006), menyatakan ada tiga faktor yang menjadi penyebab terjadinya kecurangan, yaitu: kesempatan/peluang, rasionalisasi, dan dorongan/tekanan. Ketiga faktor tersebut disebut fraud triangle (segitiga kecurangan akuntansi). Sementara dalam Teori Gone menyatakan terdapat 4 faktor yang mendorong seseorang melakukan kecurangan, yaitu Greed (keserakahan), opportunity (kesempatan), need (kebutuhan), dan exposure (pengungkapan). Faktor greed dan need merupakan faktor yang berhubungan dengan individu pelaku kecurangan (disebut juga faktor individual). Sedangkan faktor opportunity dan exposure merupakan faktor yang berhubungan dengan organisasi sebagai korban perbuatan kecurangan (disebut juga faktor generik/umum).

Berdasarkan data yang diperoleh dari Indonesia Corruption Watch (ICW) selama tahun 2015 diketahui bahwa ada sebanyak 212 orang yang berlatar belakang sebagai pejabat atau pegawai kementerian/pemda. Di urutan kedua yang banyak melakukan tindak pidana korupsi adalah dari swasta, mulai dari Direktur, Komisaris, konsultan dan pegawai swasta sebanyak 97 orang. Latar belakang kepala desa, camat, lurah menempati posisi ketiga sebagai aktor terkorup sebanyak 28 orang. Latar belakang seperti Kepala Daerah (27 orang), Kepala Dinas (26 orang) dan Anggota DPR/DPRD/ DPD (24 orang), pejabat atau pegawai lembaga negara lain (12 orang), direktur, pejabat, pegawai BUMN/BUMD (10 orang), kelompok masyarakat (10 orang), pejabat atau pegawai bank (10 orang) mengikuti posisi berikutnya secara berurut.

Pada pemerintah daerah Sulawesi Utara terdapat beberapa kasus yang diutarakan media mengenai adanya kerugian negara yang terjadi di Sulawesi Utara serta berita mengenai temuan-temuan dari BPK-RI dan BPKP. Pada tahun 2012 lewat media Sulawesi Utara dikatakan bahwa Penggunaan belanja Hibah belum didukung bukti pertanggungjawaban yang lengkap sebesar Rp 7.550.523.000,00 di Pemkab Bolaang Mongondow, belanja bantuan sosial kepada masyarakat belum dipertanggungjawabkan oleh penerima minimal sebesar Rp 8.860.602.324,00 pada Kota Manado, prosedur penganggaran belanja hibah menunjukan pengendalian yang kurang memadai pada Provinsi Sulawesi Utara, mekanisme pemberian dan pertanggungjawaban bantuan sosial belum memadai pada Kabupaten Bolaang Mongondow Timur, terdapat tunggakan pajak lama yang berlarut-larut penyelesaiannya dan belum tertagih minimal sebesar Rp 2.341.785.703,00 di Kota Manado, kebijakan pengurangan tarif sehingga menyebabkan potensi penerimaan pajak bioskop tidak terpungut minimal sebesar Rp 2.282.353,35 di Kota Manado, penerimaan lain-lain dari PT Air Manado belum diterima sebesar Rp 6.900.000,00 di Kota Manado, terdapat indikasi pajak hotel dibayarkan kurang dari nilai pajak yang sewajarnya minimal sebesar Rp 5.136.254.514,00 di Kota Manado, penetapan sistem taksasi pada wajib pajak tidak tepat sehingga potensi penerimaan pajak daerah tidak optimal sebesar Rp 4.341.932.794,25 di Kota Manado. Terdapat 53 temuan juga diungkapkan Kepala BPK Perwakilan Sulawesi Utara yakni 26 temuan merupakan kelemahan desain dan penerapan sistem penganggaran yang intern dan 27 temuan terkait kepatuhan terhadap perundang-undangan. Beberapa permasalahan yang menjadi dasar BPK dalam memberikan opini antara lain Pemerintah Provinsi Sulawesi Utara belum mencatat penyertaaan modal terhadap perusahaan daerah pembangunan, Pemerintah Provinsi belum menerapkan penyusutan atas aset sehingga nilai buku aset masih menunjukkan nilai yang sama dengan harga perolehannya, Pemerintah Provinsi Sulawesi Utara telah merealisasikan bantuan keuangan kepada partai politik dan atas penyaluran bantuan tersebut masih ada partai politik yang tidak mempertanggungjawabkan bantuan yang diterima pemerintah provinsi, dll. Pada tahun 2013, BPK-RI perwakilan Sulawesi Utara menyampaian hasil laporan keuangan Pemerintah Provinsi Sulawesi Utara dan pemerintah 15 kabupaten/kota di Sulawesi Utara, ditemukan ada 154 kasus yang merugikan daerah dengan nilai Rp39.880.987.915. Dan berdasarkan dari hasil pemeriksaan yang dilakukan oleh BPK-RI pada tahun 2014, provinsi Sulawesi Utara mendapatkan opini WTP (Wajar Tanpa Pengecualian) yang didasarkan pada hasil pengamatan dan evaluasi atas pengendalian intern pemerintah, dan kepatuhan terhadap peraturan perundang-undangan dimana sebelumnya pada tahun 2013 masih mendapat opini WDP (Wajar Dengan Pengecualian).

Berdasarkan laporan hasil pengawasan atas akuntabilitas keuangan negara/daerah pada provinsi Sulawesi Utara tahun 2014 disebutkan bahwa permasalahan dalam pengelolaan dan pelaporan keuangan di wilayah Provinsi Sulawesi Utara secara umum berkaitan dengan kelemahan sistem pengendalian intern, meliputi pengelolaan anggaran dan barang milik negara/daerah belum dilaksanakan dengan tertib; penatausahaan pajak dan retribusi daerah yang tidak tertib dan belanja hibah serta bantuan sosial yang belum didukung dengan laporan pertanggungjawabannya; ketidaktaatan terhadap ketentuan meliputi pelaksanaan pengadaan barang dan jasa, serta pengelolaan anggaran yang 
tidak sesuai dengan ketentuan yang berlaku; serta pertanggungjawaban belanja yang tidak didukung dengan bukti yang memadai, penyajian laporan keuangan yang belum sesuai dengan Standar Akuntansi Pemerintahan (SAP); kelemahan dalam sistem penyusunan laporan keuangan, kurang memadainya kompetensi SDM pengelola keuangan pada pemda. Laporan tersebut juga memaparkan permasalahan utama yang ditemukan dalam pengelolaan Barang Milik Daerah Provinsi Sulawesi Utara secara umum dimana terdapat peralatan dan mesin yang ada pada SKPD belum diketahui status keberadaannya, dalam kondisi rusak dan beberapa diantaranya dinyatakan hilang; aset tetap jalan, irigasi dan jaringan tidak didukung dengan data identitas jalan seperti panjang, lebar, dan luas jalan, letak lokasi alamat serta dokumen pengadaan; aset tetap dari hibah dan kapitalisasi belum dicatat dan penghapusan aset tanpa Surat Keputusan Kepala Daerah; terdapat perbedaan aset tetap yang disajikan pada neraca dengan nilai yang tercatat pada Laporan Barang Milik Daerah (BMD) bidang aset maupun SKPD; aset yang dikuasai pihak lain, tidak diketahu keberadaannya sehingga tercatat pada Buku Inventaris tanpa rincian jumlah unit yang sebenarnya.

Terdapat beberapa penelitian di bidang etika menggunakan teori perkembangan moral untuk menilai dasar individu melakukan suatu tindakan. Salah satu yang sering digunakan adalah teori mengenai level penalaran moral Kohlberg. Mengetahui level penalaran moral seseorang akan menjadi dasar untuk mengetahui kecenderungan individu melakukan suatu tindakan tertentu, terutama yang berkaitan dengan dilema etika, berdasarkan level penalaran moralnya. Aranta (2013) menyatakan bahwa dengan mengetahui sifat dan karakteristik manusia dalam melakukan kecurangan, pemerintah dapat mengurangi kemungkinan terjadinya kecurangan. Penelitian ini juga kecenderungan kecurangan akuntansi. Pradnyani (2014) menyatakan bahwa keefektifan pengendalian internal mempunyai pengaruh yang besar dalam upaya pencegahan kecenderungan kecurangan akuntansi, dengan adanya pengendalian internal maka pengecekan akan terjadi secara otomatis terhadap pekerjaan seseorang oleh orang lain. Selain moralitas individu dan keefektifan pengendalian internal, penelitian ini juga ingin mengetahui apakah asimetri informasi merupakan indikator yang mempengaruhi kecenderungan kecurangan akuntansi. Asimetri informasi adalah ketidakseimbangan informasi yang dimiliki oleh principal dan agen, ketika principal tidak memiliki informasi yang cukup tentang kinerja agen, sebaliknya agen memiliki lebih banyak informasi mengenai kapasitas diri, lingkungan kerja dan perusahaan secara keseluruhan (Senja, 2011). Dalam penelitian yang dilakukan oleh Aranta (2013) menunjukkan adanya hubungan positif asimetri informasi terhadap kecenderungan kecurangan akuntansi, yang berarti semakin tinggi asimetri informasi, maka kecenderungan kecurangan akuntansi semakin meningkat. Penelitian ini dilakukan pada Badan Pengelola Keuangan dan Barang Milik Daerah Propinsi Sulawesi Utara berdasarkan persepsi pegawai. Pegawai Badan Pengelola Keuangan dan Barang Milik Daerah dinilai tepat untuk menjadi responden penelitian karena tugas mereka melaksanakan penyusunan dan pelaksanaan kebijakan daerah yang bersifat spesifik di bidang pengelola keuangan dan barang milik daerah.

Penelitian ini mempunyai tujuan untuk menganalisis:

1) Pengaruh moralitas individu terhadap kecenderungan kecurangan (fraud)

2) Pengaruh asimetri informasi terhadap kecenderungan kecurangan (fraud)

3) Pengaruh keefektifan pengendalian internal terhadap kecenderungan kecurangan (fraud) Sebagaimana pada gambar I

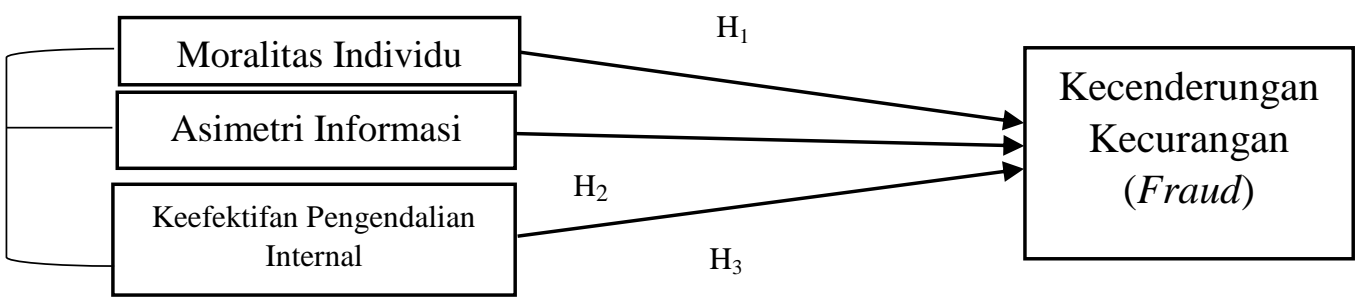

Gambar I. Kerangka Konseptual

Moralitas adalah sebuah perbuatan atau tingkah laku baik atau buruk. Moral atau tingkah laku juga akan menjadi faktor pemicu kecurangan (Amin, 2009). Kecurangan dalam suatu perusahaan atau lembaga dipengaruhi oleh para karyawan yang bekerja didalamnya. Lembaga tersebut tentu memiliki karyawan yang bekerja di masing-masing bagiannya dengan tingkat moralitas setiap individu yang 
beragam dan akan berpengaruh pada adanya adanya kecenderungan kecurangan (fraud) yang mungkin timbul.

Menurut Wilopo (2006) semakin tinggi moralitas manajemen semakin rendah kecenderungan kecurangan akuntansi atau semakin tinggi tahapan moralitas manajemen semakin manajemen memperhatikan kepentingan yang lebih luas dan universal daripada kepentingan perusahaan semata, terlebih kepentingan pribadi. Puspasari (2012) mengungkapkan bahwa orang dengan level penalaran moral rendah cenderung melakukan hal-hal yang dianggap menguntungkan diri sendiri dan cenderung berusaha untuk menghindarkan dari dari sanksi yang akan berlaku. Hal itu berarti bahwa semakin tinggi moralitas individu maka individu tersebut akan lebih memperhatikan kepentingan bersama dibandingkan kepentingan golongan atau pribadi. Sehingga individu yang memiliki level penalaran moral yang tinggi cenderung tidak ingin melakukan tindakan yang menyimpang yang bisa merugikan orang lain ataupun tidak memiliki perilaku untuk melakukan kecurangan.

Asimetri informasi adalah ketidakseimbangan informasi yang dimiliki oleh principal dan agen, ketika principal tidak memiliki informasi yang cukup tentang kinerja agen, sebaliknya agen memiliki lebih banyak informasi mengenai kapasitas diri, lingkungan kerja, dan perusahaan secara keseluruhan (Senja, 2011). Aranta (2013) menyatakan bahwa terjadinya asimetri informasi antara atasan dan bawahan dapat mempengaruhi laporan keuangan yang bisa memyebabkan kecurangan. Hal tersebut disebabkan karena seharusnya laporan keuangan tersebut penting bagi para pengguna eksternal terutama sekali karena kelompok ini berada dalam kondisi yang paling besar ketidakpastiannya. Jika terjadi kesenjangan informasi maka dapat membuka peluang bagi pihak pengelola dana untuk melakukan kecurangan dengan kata lain, asimetri informasi antara atasan dan bawahan dapat mempengaruhi laporan keuangan bisa menimbulkan adanya kecurangan.

Sistem pengendalian internal berperan penting dalam mengantisipasi terjadinya kecurangan. Dalam penelitian Wilopo (2006) menyebutkan bahwa semakin efektif pengendalian internal maka dapat mengurangi kecenderungan kecurangan. Keefektifan pengendalian internal dapat mengurangi tindakan menyimpang bahkan menutup peluang adanya perilaku kecenderungan dalam melakukan kecurangan-kecurangan yang biasanya dipicu oleh kepentingan pribadi. Coram et al. (2008) menemukan bahwa organisasi yang memiliki fungsi audit internal akan lebih dapat mendeteksi kecurangan akuntansi dan melaporkannya sendiri. Sehingga dapat disimpukan bahwa dengan adanya pengendalian internal yang efektif dan baik maka keinginan seseorang untuk melakukan kecurangan sulit untuk diwujudkan.

\section{Metode Penelitian}

Penelitian ini merupakan jenis penelitian kuantitatif yang bertujuan untuk menganalisis pengaruh moralitas individu $\left(\mathrm{X}_{1}\right)$, asimetri informasi $\left(\mathrm{X}_{2}\right)$, dan keefektifan pengendalian internal $\left(\mathrm{X}_{3}\right)$ sebagai variabel independen terhadap kecenderungan kecurangan $(\mathrm{Y})$ sebagai variabel dependen. Teknik analisis yang digunakan adalah analisis regresi linear berganda.

Penelitian ini dilakukan pada Badan Pengelola Keuangan dan Barang Milik Daerah Provinsi Sulawesi Utara. Populasi yang digunakan adalah seluruh pegawai Badan Pengelola Keuangan dan Barang Milik Daerah Provinsi Sulawesi Utara. Metode yang digunakan dalam penarikan sampel ini adalah sampling jenuh atau sensus. Karena jumlah populasi yang sedikit (terbatas), maka peneliti menjadikan seluruh populasi sebagai sampel.

Moralitas individu diukur melalui 6 (enam) butir instrumen yang mengukur setiap tahapan moralitas individu. Asimetri informasi diukur dengan 5 indikator yaitu informasi yang dimiliki eksekutif dibandingkan dengan legislatif, hubungan input dan output yang ada dalam operasi internal, kinerja Potensial, mampu menilai dampak potensial, pencapaian bidang kegiatan. Keefektifan pengendalian internal diukur dengan 5 indikator yang merupakan unsur-unsur terciptanya pengendalian internal yang efektif. Kecenderungan kecurangan diukur dengan 5 indikator yaitu kecenderungan untuk melakukan manipulasi, pemalsuan atau merubah catatan akuntansi atau dokumen pendukungnya, kecenderungan untuk melakukan penyajian yang salah atau penghilangan peristiwa, transaksi, atau informasi yang signifikan dari laporan keuangan, kecenderungan untuk melakukan salah menerapkan prinsip akuntansi secara sengaja, kecenderungan untuk melakukan penyajian laporan keuangan yang salah akibat pencurian (penyalahgunaan/penggelapan) terhadap aktiva yang membuat entitas membayar barang/jasa yang tidak diterima, kecenderungan untuk melakukan penyajian laporan keuangan yang salah akibat perlakuan yang tidak semestinya terhadap aktiva yang disertai dengan catatan atau dokumen palsu dan dapat menyangkut satu atau lebih individu diantara manajemen, karyawan atau pihak ketiga. 


\section{Hasil dan Pembahasan}

Data dalam penelitian ini dikumpulkan dengan cara menyebarkan kuesioner langsung kepada 75 responden. Dari jumlah yang disebarkan tersebut terkumpul sebanyak 65 kuesioner. Uji validitas diakukan dengan melakukan korelasi antar skor butir pertanyaan dengan total skor konstruk atau variabel. Uji signifikansi dilakukan dengan membandingkan nilai $r$ hitung dengan $r$ tabel (lihat $r$ tabel Product Moment dengan uji dua sisi pada lampiran). Jika $r$ hitung $>r$ tabel dan nilai positif maka pertanyaan tersebut dinyatakan valid. Peneliti telah melakukan uji validitas untuk setiap pertanyaan dari kuesioner dan hasil yang diperoleh dari masing-masing pertanyaan adalah valid.

Analisa reliabilitas dilakukan dengan menguji statistik Cronbach Alpha. Suatu konstruk atau variabel dikatakan reliabel jika memberikan nilai Cronbach Alpha $>0,60$. Hasil uji reliabilitas untuk variabel dependen dan independen yang didapat peneliti berdasarkan output SPSS adalah $>0.60$ sehingga dapat dikatakan bahwa variabel-variabel tersebut reliabel.

Uji Normalitas dilakukan untuk mengetahui apakah data sampel memenuhi persyaratan distribusi normal. Persyaratan data tersebut normal jika probabilitas atau $\mathrm{p}>0.05$ pada uji normalitas dengan Kolmogorov-Smirov (K-S). Hasil uji normalitas dinyatakan memenuhi persyaratan distribusi normal.

Untuk menguji ada tidaknya multikolinearitas dalam suatu model regresi salah satunya dengan melihat nilai tolerance dan lawannya, dan Variance Inflation Factor (VIF). Kedua ukuran ini menunjukkan setiap variable independen manakah yang dijelaskan oleh variable sama dengan nilai VIF tinggi (karena VIF $=1$ /Tolerance) dan menunjukkan adanya kolinearitas tinggi. Nilai Cut Off yang umum dipakai untuk menunjukkan adanya multikolinearitas adalah nilai Tolerance $<0.10$ atau sama dengan nilai VIF $>10$. Bila nilai tolerance $>0.10$ atau sama dengan nilai VIF $<10$, berarti tidak ada multikolinearitas antar variable dalam model regresi. Hasil yang diperoleh bebas multikolinearitas antar variabel independen dalam model regresi.

Uji Autokorelasi bertujuan menguji apakah dalam model regresi linear ada korelasi antara kesalahan pengganggu pada periode $t$ dengan kesalahan pengganggu pada periode $\mathrm{t}-1$ (sebelumnya). Jika terjadi korelasi, maka dinamakan problema autokorelasi. Hasil pengujian analisis regresi tidak terdapat autokorelasi positif dan tidak terdapat autokorelasi negatif sehingga bisa disimpulkan sama sekali tidak terdapat autokorelasi.

Model yang baik adalah tidak terjadi heteroskedastisitas. Hasil uji Heterokedastisitas menunjukkan bahwa grafik scatterplot tidak membentuk pola yang teratur seperti bergelombang, melebar ataupun menyempit, tetapi menyebar diatas maupun dibawah nilai nol pada sumbu Y sehingga dapat disimpulkan model regresi tidak mengandung heterokedastisitas. Hasil pengujian diagram pencar residual tidak membentuk suatu pola tertentu atau posisinya dalam keadaan menyebar sehingga dapat disimpulkan model regresi terbebas dari kasus heterokedastisitas.

Uji parsial (uji t) dilakukan untuk mengetahui pengaruh variabel independen secara individual terhadap variabel depeden.

Tabel 1. Hasil Regresi Berganda

\begin{tabular}{|c|c|c|c|c|c|c|}
\hline \multicolumn{7}{|c|}{ Coefficients $^{a}$} \\
\hline \multirow{2}{*}{\multicolumn{2}{|c|}{ Model }} & \multicolumn{2}{|c|}{$\begin{array}{l}\text { Unstandardized } \\
\text { Coefficients }\end{array}$} & \multirow{2}{*}{$\begin{array}{c}\begin{array}{c}\text { Standardized } \\
\text { Coefficients }\end{array} \\
\text { Beta }\end{array}$} & \multirow[b]{2}{*}{$\mathrm{t}$} & \multirow[b]{2}{*}{ Sig. } \\
\hline & & $\mathrm{B}$ & Std. Error & & & \\
\hline 1 & (Constant) & 18.364 & 2.464 & & 7.452 & .000 \\
\hline & $\mathrm{x} 1$ & -.298 & .090 & -.376 & -3.326 & .001 \\
\hline & $\mathrm{x} 2$ & .263 & .079 & .378 & 3.348 & .001 \\
\hline & $\mathrm{x} 3$ & -.294 & .111 & -.298 & -2.643 & .010 \\
\hline
\end{tabular}

a. Dependent Variable: y1

Sumber: Hasil Olahan Data (2017)

Pengujian hipotesis pada uji t untuk mengetahui pengaruh variabel independen terhadap variabel dependen secara individual dengan menggunakan kriteria yaitu apabila signifikan $<0.05$ 
maka $\mathrm{H}_{1}$ diterima dan apabila signifikan > 0.05 maka $\mathrm{H}_{1}$ ditolak. Berdasarkan nilai statistik pada tabel hasil analisis regresi linear berganda, dapat dilihat bahwa nilai koefisien moralitas individu negatif 0.298 yang berarti moralitas individu memiliki hubungan yang berlawanan arah dengan kecenderungan kecurangan (fraud) dimana setiap kenaikan moralitas individu satu satuan maka variabel $\mathrm{Y}$ akan turun sebesar 0.298 , sementara variabel $\mathrm{X}_{1}$ memiliki nilai signifikansi $=0.001<\alpha=$ 0.05 , maka dapat disimpulkan bahwa $\mathrm{H}_{1}$ diterima, maka variabel bebas $\mathrm{X}_{1}$ berpengaruh signifikan terhadap variabel terikat $(Y)$. Selanjutnya untuk variabel $\mathrm{X}_{2}$ nilai koefisien adalah positif 0.263 yang berarti menunjukkan hubungan yang searah dengan variabel $\mathrm{Y}$ dimana setiap kenaikan satu satuan variabel $\mathrm{X}_{2}$ maka variabel juga akan mengalami kenaikan sebesar 0.263 , sementara variabel $\mathrm{X}_{2}$ memiliki nilai signifikansi $=0.001<\alpha=0.05$, maka dapat disimpulkan bahwa $\mathrm{H}_{2}$ diterima, berarti variabel bebas $\mathrm{X}_{2}$ berpengaruh signifikan terhadap variabel terikat $(\mathrm{Y})$. Dan berdasarkan nilai statistik pada tabel hasil analisis regresi berganda, nilai koefisien $X_{3}$ adalah negatif 0.294 sehingga berlawanan arah dengan variabel $\mathrm{Y}$ dimana setiap kenaikan satu satuan variabel $\mathrm{X}_{3}$ maka variabel $\mathrm{Y}$ akan mengalami penurunan sebesar 0.294, sementara variabel $\mathrm{X}_{3}$ memiliki nilai signifikansi $=0.010<\alpha=$ 0.05 , maka dapat disimpulkan bahwa $\mathrm{H}_{3}$ diterima, maka variabel bebas $\mathrm{X}_{3}$ berpengaruh signifikan terhadap variabel terikat (Y).

Model regresi linear berganda pada penelitian ini adalah:

$$
Y=18.364-0.298 X_{1}+0.263 X_{2}-0.294 X_{3}
$$

Koefisien Determinasi $\left(\mathrm{R}^{2}\right)$ sebesar 0.302 yang memiliki arti bahwa pengaruh variabel bebas $\mathrm{X}_{1}, \mathrm{X}_{2}$, dan $\mathrm{X}_{3}$ terhadap perubahan variabel terikat $\mathrm{Y}$ adalah sebesar $30.2 \%$ dan sisanya $69.8 \%$ dipengaruhi oleh variabel lain diluar variabel bebas yang digunakan dalam penelitian ini. Nilai koefisien $\mathrm{R}$ yang positif menunjukkan pengaruh hubungan yang searah atau jika nilai variabel bebas naik maka nilai variabel terikat juga naik.

\section{Pengaruh Moralitas Individu terhadap Kecenderungan Kecurangan (Fraud)}

Hasil dalam penelitian ini variabel moralitas individu $\left(\mathrm{X}_{1}\right)$ memiliki nilai signifikansi $=0.001$ $<\alpha=0.05$ dan nilai koefisien negatif 0.298. Maka disimpulkan bahwa moralitas individu $\left(\mathrm{X}_{1}\right)$ mempunyai pengaruh signifikan negatif terhadap kecenderungan kecurangan $(\mathrm{Y})$. Hal ini sejalan dengan penelitian yang dilakukan oleh Wilopo (2006) yang menunjukkan bahwa semakin tinggi level penalaran moral seseorang maka kecenderungan untuk melakukan kecurangan akan semakin berkurang. Prawira dkk (2014) juga mengemukakan bahwa moralitas individu akan mempengaruhi kecenderungan seseorang melakukan kecurangan akuntansi yang artinya semakin tinggi tahapan moralitas individu, semakin individu memperhatikan kepentingan yang lebih luas dan universal daripada kepentingan organisasi semata, apalagi kepentingan individu. Dengan demikian, semakin tinggi moralitas individu seseorang maka kemungkinan orang tersebut memiliki kecenderungan kecurangan akuntansi akan semakin rendah.

\section{Pengaruh Asimetri Informasi terhadap Kecenderungan Kecurangan (Fraud)}

Hasil pengujian terhadap variabel asimetri informasi $\left(\mathrm{X}_{2}\right)$ terhadap kecenderungan kecurangan akuntansi (Y) memiliki nilai signifikansi $=0.001<\alpha=0.05$ dan nilai koefisien positif 0.263 , Maka dapat disimpulkan bahwa asimetri informasi memiliki pengaruh signifikan positif terhadap kecenderungan kecurangan (fraud). Hasil studi ini sesuai dengan hasil Aranta (2008) yang menunjukkan bahwa asimetri informasi berpengaruh signifikan positif terhadap kecenderungan kecurangan. Artinya, semakin tinggi asimetri informasi maka kecenderungan kecurangan akuntansi akan semakin meningkat. Sebaliknya, jika asimetri informasi semakin rendah maka kecenderungan kecurangan akuntansi akan semakin menurun atau berkurang.

\section{Pengaruh Keefektifan Pengendalian Internal terhadap Kecenderungan Kecurangan (Fraud)}

Variabel keefektifan pengendalian internal $\left(\mathrm{X}_{3}\right)$ memiliki nilai signifikansi $=0.010<\alpha=0.05$ dan nilai koefisien negatif 0.294 . Maka dapat disimpulkan bahwa keefektifan pengendalian internal mempunyai pengaruh signifikan negatif terhadap kecenderungan kecurangan (fraud). Hal ini sejalan dengan beberapa penelitian yang sudah dilakukan oleh Pradnyani (2014) dan Saridewi (2014) dimana hasil penelitian menunjukkan bahwa pengendalian internal mempunyai pengaruh signifikan negatif terhadap kecenderungan kecurangan akuntansi. Semakin efektif pengendalian internal yang diterapkan maka semakin rendah kecurangan akuntansi mungkin akan terjadi. 


\section{Kesimpulan dan Saran}

Berdasarkan pembahasan dan hasil analisa dari penelitian yang sudah dilakukan, maka diperoleh kesimpulan sebagai berikut:

1. Hasil dalam penelitian ini variabel moralitas individu $\left(\mathrm{X}_{1}\right)$ memiliki nilai signifikansi $=0.001$ $<\alpha=0.05$ dan nilai koefisien negatif 0.298 . Maka disimpulkan bahwa moralitas individu $\left(\mathrm{X}_{1}\right)$ mempunyai pengaruh signifikan negatif terhadap kecenderungan kecurangan (Y). Artinya, semakin tinggi level penalaran moral seseorang semakin ia akan menghindarkan diri dari kecenderungan melakukan kecurangan.

2. Untuk variabel $X_{2}$, Hasil pengujian terhadap variabel asimetri informasi $\left(X_{2}\right)$ terhadap kecenderungan kecurangan $(\mathrm{Y})$ memiliki nilai signifikansi $=0.001<\alpha=0.05$ dan nilai koefisien positif 0.263 , Maka dapat disimpulkan bahwa asimetri informasi memiliki pengaruh signifikan positif terhadap kecenderungan kecurangan (fraud). Artinya, asimetri informasi yang tinggi akan memperbesar kecenderungan kecurangan.

3. Dari hasil studi variabel keefektifan pengendalian internal $\left(\mathrm{X}_{3}\right)$ memiliki nilai signifikansi $=$ $0.010<\alpha=0.05$ dan nilai koefisien negatif 0.294. Maka dapat disimpulkan bahwa keefektifan pengendalian internal mempunyai pengaruh signifikan negatif terhadap kecenderungan kecurangan $($ fraud $)$. . Artinya, Semakin efektif pengendalian internal yang diterapkan maka semakin rendah kecurangan akuntansi mungkin akan terjadi. berikut:

Berdasarkan hasil penelitian yang dilakukan adapun saran yang dapat diberikan sebagai

1. Penelitian berikutnya bisa memperluas objek penelitian sehingga hasil yang kemudian akan diperoleh dapat lebih maksimal.

2. Penelitian berikutnya harus mempertimbangkan faktor-faktor atau variabel lain yang mempengaruhi kecenderungan kecurangan akuntansi sehingga dapat dibandingkan dengan hasil dari penelitian lain.

\section{Daftar Pustaka}

Amin, Widjaja. 2009. Kecurangan Laporan Keuangan (Financial Statement Fraud), Jakarta: PT. Indeks.

Aranta, P. Z. 2013. "Pengaruh Moralitas Aparat dan Asimetri Informasi Terhadap Kecendrungan Kecurangan Akuntansi (Studi Empiris Pemerintah Kota Sawahlunto)”. Jurnal Program Studi Akuntansi Universitas Negeri Padang.

Black's Law Dictionary. 1990. 6th Edition. St. Paul, MN: West Publishing Co.

COSO. 2013. Internal Control Framework Resources.

Coram, P., et al. 2008. The Mortal Intensity of Reduced Audit Quality Acts. A Journal of Practice \& Theory. 19(1), pp: 123-148.

Cressey, Donald R. 2006. Others people money, A study in the social psychology of Embezzlement. Montclair: Patterson Smith.

Dugaan Penyimpangan Hasil Temuan Perwakilan BPK-RI Sulut diakses dari www.sulutonline.com/berita/671-dugaan-penyimpangan-hasil-temuan-perwakilan-bpk-risulut.html.

Ikatan Akuntan Indonesia. 2001. Standar Profesional Akuntan Publik (SA 316) Pertimbangan atas Kecurangan dalam Audit Laporan Keuangan

Ikatan Akuntan Indonesia. 2001. Standar Profesional Akuntan Publik. Standar Auditing Seksi 316. Pertimbangan atas Kecurangan dalam Audit Laporan Keuangan.

Indonesia Corruption Watch (ICW). (2015). Diakses melalui http://antikorupsi.org

Kohlberg, L. 1971. Stage and sequence: The cognitive-development approach moral action to socialization. In D. A. Goslin (Ed). Handbook of socialization theory and research. Chicago: RandMcNally.

Laporan Hasil pengawasan atas Akuntabilitas Keuangan Negara/Daerah pada Provinsi Sulawesi Utara tahun 2014 diakses melalui www.bpkp.go.id/public/upload/unit/sulut/files/LHP2014.pdf

Peraturan Pemerintah Nomor 60 Tahun 2008 tentang Sistem Pengendalian Intern Pemerintah. Presiden Republik Indonesia. Jakarta

Pradnyani, Ni Luh Putu Normadewi Abdi. 2014. "Pengaruh Keefektifan Pengendalian Internal, Ketaatan Aturan Akuntansi, dan Asimetri Informasi pada Akuntabilitas Organisasi dengan 
Kecenderungan Kecurangan Akuntansi sebagai Variabel Intervening (Studi Empiris pada Perguruan Tinggi Negeri di Provinsi Bali)". Denpasar : Unversitas Udayana.

Puspasari. 2012. "Pengaruh Moralitas Individu dan Pengendalian Internal terhadap Kecenderungan

Kecurangan Akuntansi: Studi Eksperimen pada Konteks Pemerintah Daerah". Jurnal.

Yogyakarta : FEB UGM.

Senja, Miranti. 2011. "Pengaruh Asimetri Informasi Dan Ukuran Perusahaan Terhadap Manajemen

Laba di PT BEI". Skripsi S1. FE UNP.

Tunggal, Amin Widjaya. 2001, Internal Auditing (Suatu Pengantar), Jakarta: Harvarindo Wilopo. 2006. Analisis Faktor-Faktor yang Berpengaruh Terhadap Kecenderungan Kecurangan Akuntansi : Studi pada Perusahaan Publik dan Badan Usaha Milik Negara (BUMN) di Indonesia. Jurnal Riset Akuntansi Indonesia vol.9. 